\title{
MANIFESTASI IDENTITAS ISLAM SUKU BAJO DALAM NASKAH LONTARAK ASSALENNA BAJO
}

\author{
Benny Baskara \\ Inter Religius Studies (IRS) Sekolah Pascasarjana UGM Yogyakarta \\ Email: benbasku@gmail.com dan bensk@yahoo.co.uk
}

\begin{abstract}
The Bajo people are known as the sea wanderers because they always wander the sea. However, aside from their unique characteristic as people of the sea, the Bajo are also known as Muslims. Therefore, Islam is an important element of their identity, either reflected in their daily life or written in the manuscript Lontarak Assalenna Bajo as the form of self-narration of their cultural history. Islam has been accepted through a continual process of negotiation and development. The Bajo people were not Muslim before they became sea wanderes. They received the influence of Islam from the land-bound people surrounding them as a result of interactions between the two groups.
\end{abstract}

Keywords: Bajo, Islam, identity

\begin{abstract}
ABSTRAK
Suku Bajo dikenal sebagai suku pengembara laut karena kebiasaan hidupnya yang mengembara di lautan lepas. Namun demikian, di samping karakteristiknya yang unik sebagai pengembara laut tersebut, suku Bajo ternyata beragama Islam. Dengan demikian, Islam telah menjadi bagian dari identitas orang Bajo, yang tercermin dari kehidupan mereka sehari-hari maupun tercantum dalam naskah "Lontarak Assalenna Bajo"sebagai catatan tentang kehidupan masyarakat Bajo yang ditulis oleh mereka sendiri. Islam diterima oleh orang Bajo tidak secara serta merta, namun melalui proses negosiasi dan perkembangan terus-menerus. Orang Bajo bukanlah orang Islam dari awal sebelum mereka menjadi pengembara laut, namun mereka menerima pengaruh Islam dari orang-orang darat di sekitarnya sebagai akibat dari hubungan mereka dengan orang-orang darat.
\end{abstract}

\section{Kata kunci: Bajo, Islam, identitas}




\section{PENGANTAR}

Suku Bajo dikenal sebagai suku pengembara laut karena kebiasaan hidup mereka yang selalu mengembara mengarungi lautan. Beberapa penelitian yang telah dilakukan tentang suku Bajo antara lain menyebut mereka sebagai "Suku Pengembara Laut" (Zacot, 2008), "Sea Nomads" (Sopher, 1965; Chou, 2003), atau "Sea People" (Nimmo, 1972, 2001; Sather, 1997). Sebagai suku pengembara laut, suku Bajo tidak hanya dijumpai di wilayah perairan Indonesia saja, tetapi juga hampir di seluruh wilayah perairan Asia Tenggara, dan mungkin juga di wilayah-wilayah perairan lainnya. Suku Bajo pada zaman dahulu memang mengembara di lautan lepas dengan perahu-perahu tradisional mereka yang disebut leppa. Namun saat ini, mereka telah banyak bermukim di tepi-tepi pantai maupun gugusan-gugusan karang. Pemukiman tersebut tetap didirikan di atas air yang menunjukkan bahwa kehidupan mereka memang tidak bisa dilepaskan dari laut.

Sebutan "Bajo", "Suku Bajo", atau "Orang Bajo", umumnya digunakan oleh penduduk di wilayah Indonesia Timur untuk menyebut suku pengembara laut ini, yang tersebar di berbagai wilayah (Anwar, 2006). Sementara itu, di wilayah Indonesia Barat, kelompok masyarakat ini disebut "Orang Laut", "Suku Laut", atau "Rakyat Laut", sebutan yang biasa digunakan oleh Orang Melayu di Riau dan penduduk Pulau Sumatera pada umumnya, juga di Kepulauan Natuna, Malaysia Barat, serta Johor Selatan. Namun di Johor Utara, mereka disebut "Orang Kuala", sedangkan di Sabah dan Tawau di Malaysia Timur, juga di Brunei Darussalam dan Filipina, mereka disebut "Orang Bajau", "Suku Asli", "Sama Bajau", "Sama Dilaut", "Bajau Laut", "Orang Samal", atau "Samal Bajau Laut" (Anwar, 2006; Chou, 2003). Di wilayah Myanmar dan Thailand mereka disebut sebagai orang "Mawken" atau "Chao Nam" (Hope, 2001; Ahimsa-Putra, 2006).

Meskipun kelompok masyarakat ini mempunyai sebutan yang berbeda-beda ber- gantung pada letak geografis tempat mereka bermukim, namun dari sisi kebudayaan mereka memiliki kesamaan yang bisa menjadi suatu ciri khas. Karakteristik yang paling mencolok adalah pola pemukiman mereka yang umumnya didirikan di atas air di pesisir pantai atau di gugusan-gugusan karang, dan mata pencaharian utama sebagai nelayan tradisional. Selain itu, mereka juga menggunakan bahasa yang sama, adat-istiadat, kepercayaan, dan pola perilaku yang cenderung sama, yang menunjukkan suatu kesamaan budaya. Berdasarkan kesamaan budaya ini, maka bisa dikatakan bahwa mereka adalah termasuk dalam satu rumpun atau berasal dari satu rumpun yang sama (Anwar, 2006; Liliweri, 2002).

Dalam makalah ini, istilah yang digunakan untuk menyebut suku laut ini adalah "Bajo" karena mengacu pada naskah Lontarak Assalenna Bajo sebagai naskah yang ditulis oleh orang Bajo sendiri tentang sejarah kehidupan mereka. Naskah tersebut disebut oleh Anwar (2006) sebagai suatu bentuk "keluhuran dan ketinggian budaya suku Bajo karena mereka mampu menuangkan idenya dalam bahasa tulisan", bila dibandingkan dengan beberapa suku lainnya di Nusantara yang masih mengandalkan budaya tutur dan tradisi lisan dalam menceritakan sejarah kehidupannya.

Dengan karakteristiknya yang unik sebagai suku pengembara laut, yang tentunya lebih banyak menghabiskan kehidupannya dengan mengembara di lautan, ternyata orang Bajo juga penganut Islam. Dengan demikian, bisa dikatakan bahwa Islam telah menjadi bagian penting dalam identitas orang Bajo. Hal ini dibuktikan antara lain dengan pengamatan Thomas Forrest (1779, dikutip dari McAllister, 1996) sebagai berikut:

"The Badjoo people, called Orang Badjoo, are a kind of itinerent fishermen ... They lived chiefly in small covered boats on the coasts of Borneo and Celebes and adjacent islands. Others dwell close to the sea on these islands, their houses being raised on poles, a little distance into the sea ... They are Mahometans." 
Dalam penelitian La Marihi (2007) dikutip hasil sensus penduduk tahun 2000 di desa Bajo Mantigola, Kepulauan Wakatobi, menyebutkan bahwa di desa tersebut seluruhnya adalah orang Bajo dan semuanya $(100 \%)$ beragama Islam. Demikian pula dari beberapa penelitian etnografis sebelumnya (Sopher, 1965; Nimmo, 1972, 2001; Sather, 1997; Chou, 2003) bahwa ajaran-ajaran Islam itu tampak dalam kehidupan sehari-hari orang Bajo. Dari bukti-bukti tersebut, Islam memang telah menjadi bagian penting dalam identitas orang Bajo, yang di samping tercermin dalam kehidupan mereka seharihari, juga tertuang dalam tulisan tentang sejarah kehidupan mereka. Oleh karena itu, makalah ini bertujuan untuk mengungkapkan identitas keislaman orang Bajo yang tertulis dalam naskah Lontarak Assalenna Bajo.

\section{KERANGKA TEORITIK}

Dalam pandangan Liliweri (2002), bentuk identitas ada tiga macam, yaitu identitas pribadi, identitas sosial, dan identitas budaya. Identitas pribadi adalah identitas berdasarkan keunikan karakteristik pribadi yang berbeda dengan orang lain, seperti bakat, kemampuan, dan pilihan pribadi. Identitas budaya adalah karakteristik yang muncul karena seseorang itu merupakan anggota sebuah suku bangsa atau kelompok budaya tertentu. Identitas budaya meliputi proses pembelajaran dan penerimaan terhadap tradisi, ciri-ciri bawaan, bahasa, agama, dan turunan dari kebudayaan tertentu. Identitas sosial terbentuk karena seseorang menjadi anggota suatu kelompok atau komunitas tertentu dalam kebudayaan, antara lain kelompok-kelompok sosial yang berdasarkan gender, usia, kelas sosial, profesi, agama, dan lokasi tertentu (Liliweri, 2002: 96-97).

Identitas budaya terbentuk di dalam struktur kebudayaan dan peran-peran dalam struktur tersebut, yang meliputi polapola persepsi, pemikiran, dan perasaan. Pola-pola kebudayaan memengaruhi identitas seseorang, terutama dalam membentuk identitas dari gagasan-gagasan dan pemikiran-pemikiran tertentu, yang pada giliran- nya akan membimbing perilaku seseorang. Hal yang penting di sini adalah identitas itu selalu terbentuk dalam struktur kebudayaan dan struktur sosial. Makna identitas budaya adalah karakteristik suatu kebudayaan yang kita ketahui batas-batasnya, dibandingkan dengan kebudayaan-kebudayaan lainnya. Identitas budaya tidak hanya bermakna karakter fisik semata, namun lebih bermakna sebagai suatu sistem dan menunjukkan suatu tata cara, motivasi, dan orientasi berpikir, merasa, dan bertindak (Liliweri, 2002: 72).

Dari kerangka pemikiran Liliweri (2002) di atas, hal yang ingin ditegaskan di sini Lontarak Assalena Bajo merupakan cerminan dari identitas budaya masyarakat Bajo secara umum. Dalam hal ini, naskah Lontarak Assalena Bajo adalah naskah yang ditulis oleh orang Bajo sendiri mengenai kehidupan mereka, yang merupakan artikulasi dari persepsi, gagasan, dan pemikiran orang Bajo. Lebih jauh, naskah Lontarak Assalena Bajo juga merupakan rujukan untuk tata cara, motivasi, serta orientasi berpikir, merasa, dan bertindak orangorang Bajo, yang membimbing perilaku orang Bajo dalam menjalani kehidupan sebagai suatu masyarakat.

Stuart Hall (1996) menyatakan bahwa konsep tentang identitas tidak bisa dilepaskan dari konsep tentang diri dan identifikasi. Identifikasi merupakan proses artikulasi dan pengakuan diri dalam hubungannya dengan faktor-faktor yang berpengaruh di sekitarnya. Dengan demikian, identifikasi selalu berada dalam proses pembentukan. Dalam hubungannya dengan sejarah, identitas merupakan subjek konstruksi historis, dan selalu berada dalam proses perubahan dan transformasi. Identitas selalu dibangun dalam perkembangan historis dan praktikpraktik dalam masyarakat dan kebudayaan. Identitas dibangun dalam diskursus, dan identitas dihasilkan dalam rentang historis dan institusional tertentu dalam bentuk-bentuk diskursus yang spesifik.

Di sini, konsep identitas bukanlah konsep esensialis, melainkan strategis dan posisional. Artinya, konsep identitas bukanlah 
sesuatu yang stabil dalam diri manusia, sesuatu yang permanen dari awal sampai akhir tanpa perubahan. Identitas bukanlah sesuatu yang utuh, selalu terbagi-bagi dan terpilah-pilah. Identitas dibangun melalui diskursus, praktik, dan posisi yang berbedabeda, dan menjadi subjek historisasi radikal dan selalu berada dalam proses perubahan dan transformasi. Rasa memiliki (sense of belonging), yang dengannya identitas dibangun, terletak di dalam representasi simbolik dan imajiner, dan oleh karenanya bisa dikatakan berada dalam ranah fantasi atau imajiner (Hall, 1996: 4). Berdasarkan proses ini, bisa dikatakan juga bahwa identitas itu selalu berada dalam proses negosiasi.

Melalui kerangka teori dari Hall (1996) ini akan dilihat bagaimana orang Bajo mengkonstruksi dan menegosiasikan identitasnya, terutama berkaitan dengan Islam sebagai identitas religiusnya. Sebagai suku pengembara laut, suku Bajo telah mempunyai kepercayaan tradisional (indigenous belief) mereka sendiri, yaitu suatu kepercayaan terhadap penguasa lautan, yang mereka sebut sebagai Mbo Ma Dilao. Proses penerimaan nilai-nilai Islam oleh orang Bajo tentu tidak terjadi dengan serta-merta, namun melalui proses negosiasi, terutama dinegosiasikan dengan kepercayaan tradisional mereka kepada penguasa lautan atau Mbo Ma Dilao. Proses negosiasi inilah yang akan dilihat melalui teori negosiasi identitas Hall (1996) tersebut.

Identitas seseorang selalu dibentuk dalam masyarakat, demikian pendapat Berger dan Luckmann (1966). Mereka mengatakan bahwa "identitas adalah unsur kunci realitas subjektif dan berada dalam hubungan dialektis dengan masyarakat. Identitas dibentuk oleh proses sosial; identitas dibentuk, diubah, dan disesuaikan oleh hubungan-hubungan sosial." (Berger dan Luckmann, 1966: 173). Proses sosial sendiri ditentukan oleh struktur sosial; dengan demikian, pembentukan, perubahan, dan penyesuaian identitas bergantung kepada struktur sosial. Identitas seseorang juga ditentukan oleh kondisi biologisnya sebagai makhluk hidup. Hubungan antara manusia dan lingkung- annya adalah suatu bentuk hubungan yang khas, yaitu sebagai bentuk dialektika yang terus-menerus antara manusia sebagai makhluk hidup dengan situasi sosio-historisnya. Dialektika ini berlangsung secara berganda: ke luar adalah dialektika antara individu dengan lingkungan sosialnya, dan ke dalam adalah dialektika antara kebutuhan biologis individu dengan identitasnya yang terbangun secara sosial (Berger dan Luckmann, 1966: 180).

Lebih lanjut, Amartya Sen (2006) juga menegaskan bahwa identitas selalu bergantung kepada konteks sosial atau lingkungan sosial. Manusia tergabung ke dalam kelompok yang berbeda-beda, melalui kelahiran, pergaulan, dan persekutuan. Dengan keanggotaan ini, setiap identitas kelompok akan memberikan rasa keterikatan atau loyalitas, yang biasa disebut dengan "rasa memiliki" (sense of belonging). Latar belakang sosial seseorang juga selalu berbasis pada komunitas atau kebudayaan tertentu, yang menentukan proses pemikirannya dalam membuat pilihan. Pengaruh yang menentukan dalam komunitas atau kebudayaan ini berupa bentuk-bentuk pengetahuan lokal, norma, persepsi, dan nilai yang berlaku dalam komunitas atau kebudayaan tertentu (Sen, 2006: 34-35).

Dari kedua teori yang telah dipaparkan di atas, yaitu dari Berger dan Luckmann (1966) dan Amartya Sen (2006), akan dilihat bagaimana identitas Islam orang Bajo dibentuk dalam hubungannya dengan lingkungan sosial mereka, baik dinamika kehidupan sosial mereka sebagai orang laut maupun dalam hubungan mereka dengan orang darat. Dalam hal ini, bisa dikatakan bahwa Islam merupakan agama dan kepercayaan orang darat yang kemudian diterima oleh orang Bajo sebagai keyakinannya. Oleh karena itu, perlu dilihat sejarah dan dinamika hubungan antara orang Bajo dengan orang darat, sehingga proses penerimaan Islam sebagai pengaruh dari daratan oleh orang Bajo bisa diketahui.

Di antara para ahli lainnya, Hans Mol (1986) mampu memberikan gambaran yang paling jelas tentang hubungan antara iden- 
titas dan agama. Hans Mol mengemukakan empat kategori peranan agama dalam masyarakat, yang pada gilirannya juga menentukan dalam pembentukan identitas. Pertama, agama berperan dalam dramatisasi dialektika hal-hal yang mendasar dalam masyarakat. Hal tersebut lazim diketahui sebagai mitos dalam bentuk keyakinan primitif dan kebijaksanaan moral, teologi dalam agama-agama dunia, dan ideologi dalam bentuk sekuler. Mitos, teologi, dan ideologi menyediakan suatu "petunjuk" bagi individu dan masyarakat untuk kehidupan yang lebih baik (Mol, 1986: 66).

Kedua, agama membuat suatu keteraturan transendental dalam masyarakat. Semakin kompleks sebuah masyarakat, diperlukan suatu "langit suci" (sacred canopy) yang lebih luas untuk menjamin keteraturannya. Fungsi ini berkaitan dengan menjamin keadilan, keutuhan, dan kelangsungan identitas sosial. (Mol, 1986: 68).

Ketiga, agama bisa mengembangkan keterikatan emosional atau komitmen dalam masyarakat. Komitmen seringkali berkaitan erat dengan agama, yang akan membawa kepada satu kepentingan dan kehendak bersama, seperti yang dilakukan oleh sebuah suku bangsa untuk meningkatkan solidaritas internal.

Keempat, agama, terutama dalam bentuk ritual, bisa menegakkan kebersamaan dalam masyarakat. Ritual bisa memberikan rasa memiliki dan identitas bagi manusia (Mol, 1986: 70).

Berdasarkan empat kategori tersebut, Hans Mol mendefinisikan agama sebagai "sakralisasi identitas". Keyakinan, loyalitas, dan komitmen memperkuat ikatan emosional dari berbagai unsur dalam organisasi sosial, sehingga setiap unsur ini akan semakin kohesif. Di tingkat fungsional, mekanisme sakralisasi turut andil dalam konsolidasi setiap unsur dalam organisasi sosial. Agama dapat menjembatani kesenjangan dan mampu memadukan unsur-unsur dalam masyarakat. Mekanisme sakralisasi meliputi mitos, ritual, komitmen, dan transendentalisasi akan menjamin berjalan- nya fungsi dan kelangsungan hidup masyarakat (Mol, 1986: 70-71).

Melalui kerangka pemikiran Hans Mol (1986) ini akan dilihat bagaimana peran agama, khususnya Islam, dalam konstruksi identitas orang Bajo. Peran tersebut adalah bagaimana Islam menjadi petunjuk bagi kehidupan sehari-hari mereka, bagaimana Islam menjadi "langit suci" yang mampu membentuk komitmen dan kebersamaan dalam kehidupan orang Bajo. Akhirnya, bagaimana secara umum Islam menjadi sebuah "sakralisasi identitas" orang Bajo. Semua kerangka teori inilah yang akan digunakan untuk meninjau naskah Lontarak Assalenna Bajo.

\section{Naskah Lontarak Assalenna Bajo}

Naskah Lontarak Assalenna Bajo secara harfiah berarti "Lontarak tentang asal-usul suku Bajo". Naskah ini ditemukan di masyarakat Bajo di Kecamatan Lasolo, Kabupaten Kendari, Provinsi Sulawesi Tenggara, dan salinannya telah disimpan di Museum Negeri Sulawesi Tenggara di Kendari. Naskah aslinya sendiri ternyata telah lapuk dimakan usia. Naskah ini ditulis di atas kertas dengan huruf Lontarak dan Arab, dalam bahasa Bugis-Makassar dan Arab, berbentuk prosa (Anwar, 2000). Nama "lontarak" sendiri adalah nama aksara atau huruf yang digunakan dalam naskah-naskah kuno berbahasa Bugis-Makassar, yang kemudian umumnya juga dijadikan sebagai nama depan sebuah naskah. Naskah Lontarak Assalenna Bajo yang ditelaah dalam makalah ini adalah naskah yang telah diterjemahkan dan dialihaksarakan oleh Anwar (2000) ke dalam Bahasa Indonesia dengan huruf Latin.

Adapun metode yang digunakan adalah metode analisis-deskriptif- interpretatif. Naskah Lontarak Assalenna Bajo ditelaah dan dianalisis untuk mengetahui bagian-bagian atau ayat-ayat yang mengandung nilai-nilai keislaman atau bernuansa ajaran Islam. Bagian-bagian atau ayat-ayat tersebut kemudian dideskripsikan, diuraikan, dan diberikan penjelasan-penjelasan seputar konteks 
ayat-ayat atau bagian-bagian tersebut. Selanjutnya, dilakukan interpretasi atau penafsiran dari bagian-bagian atau ayat-ayat tersebut dengan kerangka teori-teori tentang identitas, untuk menjelaskan bahwa Islam telah menjadi bagian yang penting dalam identitas masyarakat Bajo.

\section{Nilai-nilai Islam yang termuat dalam Naskah Lontarak Assalenna Bajo}

Manifestasi keyakinan Islam masyarakat Bajo yang tertuang dalam naskah Lontarak Assalenna Bajo dimulai dari ayat yang pertama, yaitu pengakuan dan pujian kepada Allah, Tuhan Yang Maha Tinggi dan Nabi Muhammad sebagai utusan Allah. Bunyi ayat pertama tersebut sebagai berikut:

"Naiyya sininna pappujie, koi ri puwang Allahu Taalaa, engrengngE ri suroona Muhammad Sallallahu Alaihi Wasallama."

Terjemahan dari ayat tersebut (Anwar, 2000) adalah:

"Segala puji bagi Allah Yang Maha Tinggi dan Rasul-Nya Muhammad Sallallahu Alaihi Wasallam".

Ayat pertama sebagai pembuka naskah tersebut mencerminkan suatu ikrar keimanan kepada Tuhan Allah dan Rasul-Nya Muhammad, yang mencerminkan ucapan dua kalimat syahadat sebagai tanda keislaman seseorang yang paling mendasar, sekaligus merupakan Rukun Islam yang pertama.

Ayat kedua menyatakan bahwa orangorang Bajo itu adalah keturunan Nabi Adam dan Siti Hawa, yaitu manusia yang pertama menurut ajaran Islam dan sebagai nenek moyang seluruh manusia yang ada di muka bumi ini. Ayat kedua berbunyi sebagai berikut:

“... Naiyya ri munrinna adaE. IyyanaE, poadaadangngi, sure' lontaraE ri onro marippeE, ri asengngE mula tau. Neneeta Adang nennia neneeta Hawa iyyanatu riasengngi Opu Sengngeng mallai bine."

Terjemahan ayat tersebut (Anwar, 2000) sebagai berikut:

"Inilah yang membahas, surat lontarak dalam keadaan ringkas, mengenai asal-usul manusia pertama. Nenek kita Adam dan Hawa, yang disebut penghuni pertama bumi suami istri".

Kemudian dilanjutkan dengan ayat ketiga sebagai berikut:

"Iyyana mula-mula ripaturung ri linoE, maddeppaE, ri lapatella, nakonna riapanritannaE ri ware, nainappa ri paturung ri tanaE..."

Terjemahannya (Anwar, 2000) sebagai berikut:

“Dialah yang pertama diturunkan di dunia yang berkembang biak, karena kemuliaannya ditempatkan di atas, kemudian diturunkan di bumi..."

Dari ketiga ayat yang dikutip di atas, jelaslah bahwa orang Bajo mengakui bahwa mereka adalah orang Islam, yang berarti bahwa Islam menjadi bagian yang penting dalam identitas mereka. Namun demikian, tidak dapat diketahui dengan pasti kapan Islam pertama kali masuk dan dianut oleh orang Bajo. Dalam naskah Lontarak Assalenna Bajo sendiri tidak disebutkan kapan orang Bajo pertama kali memeluk Islam. Walaupun demikian, kita bisa melihat pada konteks naskah tersebut, sehingga kemungkinan orang Bajo memeluk Islam karena pengaruh dari kerajaan-kerajaan di sekitarnya.

Konteks naskah Lontarak Assalenna Bajo sendiri ditulis sekitar abad ke-16 hingga ke17 di wilayah BajoE, perkampungan masyarakat Bajo di teluk Bone, yang dahulu merupakan wilayah kerajaan Bone. Oleh karena itu, kemungkinan masyarakat Bajo memeluk Islam karena pengaruh dari kerajaan Bone. Dalam naskah "Lontarak Assalenna Bajo" ayat 249 disebutkan:

... salama naengkangngE tturung pole ri Mekka ri ammulangenna asengngE Syaehe Al-Hajji Yusupu, iyyana ammulangenna mappaselleng, pasellengngi to Bone nadipoanreguru tooni Petta MatinroE ri Rompegading, iyya toona ripatettong Kali ri Bone nariasenna Mupeti Yusupu.

Terjemahannya (Anwar, 2000) sebagai berikut:

“... selamat kedatangan dari Mekah pada saat pertama kalinya seorang yang bernama Syeh Haji Yusuf, dialah yang pertama kali menyebarkan Islam, mengislamkan Bone dan men- 
jadi guru Petta MatinroE ri Rompegading, dia pula diangkat menjadi Kadhi di Bone dan diberi gelar Mufti Yusuf."

Setelah kita mengetahui bahwa yang menyebarkan Islam pertama kali di kerajaan Bone adalah Syeh Haji Yusuf, keterangan selanjutnya yang tercantum dalam ayat 250 sebagai berikut:

Riwetu mappasellenna ri Bone, nauttama selleng Karaeng 1016 Hujerana Nabitta SAW, nauttama selleng to SoppengngE 1018 Hujerana Nabitta SAW, nauttama selleng to WajoE 1019 Hujerana Nabitta SAW, nauttama selleng to Bone 1020 Hujerana Nabitta SAW...

Terjemahannya (Anwar, 2000) sebagai berikut:

"Pada saat mengislamkan Bone, setelah masuknya Islam Raja Gowa tahun 1016 Hijriah (Nabi SAW), masuknya Islam orang Soppeng tahun 1018 Hijriah, masuknya Islam orang Wajo tahun 1019 Hijriah, masuknya Islam orang Bone tahun 1020 Hijriah ..."

Dari ayat di atas, diketahui bahwa Islam masuk ke kerajaan Bone adalah yang terakhir (tahun $1020 \mathrm{H}$ ), setelah Islam lebih dahulu masuk ke kerajaan-kerajaan sekitarnya, yaitu Gowa tahun 1016 H, Soppeng 1018 H, dan Wajo 1019 H. Bila diperhitungkan dengan tahun Masehi, maka periode tersebut adalah antara 1595 M sampai 1600 $\mathrm{M}$, atau pada penghujung abad ke-16 dan memasuki abad ke-17. Dari keterangan tersebut, bisa diduga bahwa Islam masuk ke suku Bajo pada periode-periode ini, karena interaksi mereka dengan orang-orang darat. Khusus untuk masyarakat Bajo di BajoE, bisa diduga Islam masuk pada sekitar abad ke17, karena pengaruh dari kerajaan Bone.

Proses penyebaran Islam di kalangan masyarakat Bajo juga tidak ditulis secara terperinci dalam Lontarak Assalenna Bajo. Hanya disebutkan bahwa ulama-ulama dari tanah Arab datang menyebarkan Islam, dan setelah Islam menyebar, minuman keras, sesajian, dan dukun tradisional dilarang. Hal tersebut disebutkan dalam ayat 228 sebagai berikut:

“Napada sempe'na lao muttama ri Bone, napada tanraapiina ri pada onro-onronna, naengka toona LoloE sibawa Ponggawa Bajo alauuna Cellu, na- pada marape'na pada mabbola, namajere'na agamaE napada engkana tuwan-tuwan Ara'E mappattareka, namajere'na berejama' $E$, naripeddenni bissu-bissuE nennia massoro-soroE, nennia tua paiE napada dee manenni sikuwaero, nariesseriattoni paimeng ade abbiasangenna BajoE ri kampong kasiwingngE ri Petta MatinroE ri Rompegading, narape'si riatettongenna paimeng TanaE ri BajoE."

Terjemahannya (Anwar, 2000) sebagai berikut:

"Mereka berlayar menuju ke Bone, sampailah mereka di tempat semula, datang pula Lolo dan Ponggawa Bajo di sebelah timur Cellu, mereka bermukim membangun rumah, berkembanglah agama, datanglah tuan-tuan orang Arab menyebarkan tarekat (Islam), ramailah jamaah shalat, dihilangkanlah BissuBissu (dukun tradisional) dan persembahan, serta minuman arak, dan hilanglah yang demikian itu, dan dikembangkan pula adat tradisi orang Bajo di kampung yang diberikan oleh Petta MatinroE ri Rompegading, maka bangkitlah kembali eksistensi negeri BajoE."

Dari ayat di atas, tampak bahwa setelah Islam disebarkan oleh ulama-ulama dari Arab, tradisi-tradisi yang bertentangan dengan ajaran Islam dilarang. Namun demikian, adat tradisi yang lain juga dikembangkan dan didukung oleh Raja Bone, Petta MatinroE ri Rompegading, sehingga kehidupan masyarakat Bajo lebih berkembang. Oleh karena itu, bisa dikatakan bahwa ajaran Islam bisa masuk dan berpadu dengan tradisi orang Bajo, dan bentuk perpaduan tersebut turut disebarluaskan melalui kekuasaan oleh Raja Bone, Petta MatinroE ri Rompegading, kepada seluruh rakyatnya, termasuk orang-orang Bajo.

Perpaduan antara ajaran Islam dengan nilai-nilai tradisional masyarakat Bajo telah terjalin erat dan dilaksanakan dalam kehidupan sehari-hari orang Bajo sebagai norma-norma dan tata aturan hidup yang harus dipatuhi. Di samping memuat sejarah kehidupan, tata kekuasaan dan sosial kemasyarakatan, naskah Lontarak Assalenna Bajo juga memuat aturan-aturan hukum yang berlaku di masyarakat Bajo. Di antara aturan-aturan tersebut, yang menunjukkan 
pengaruh ajaran Islam yang cukup kuat adalah aturan-aturan tentang tata cara perkawinan. Salah satu dari beberapa ayat yang menyebutkan tentang aturan-aturan dalam perkawinan adalah ayat 428 yang tertulis sebagai berikut:

Sibuangessi gau, ripassalenna gau abbainengngE ri sesena sompaE komui riabbatireng ammanareng$n g E$ pada rialena ripatuttungi poasengngE sompa, iyyagi na 88 (aruwa polona aruwa) iyyagi na 77 (pituppulo pitu) iyyagi na 66 (enneppulona enneng) iyyagi na 44 (patappulo eppaa) iyyagi na 22 (duwappulo duwa) iyyagi na 11 (seppulo seddi). Nako sompa 88 (aruwa polona aruwa), AdeE makeppunna 8 (aruwa) rellana, nako sompa 44 (patappulo eppaa), AdeE makeppunna 4 (eppaa) rellana, nako sompa 22 (duwappulo duwa), AdeE makeppunna 2 (duwa) rellana....

Terjemahannya (Anwar, 2000) sebagai berikut:

"Suatu perbuatan tentang perkawinan sekitar mahar yang tergantung pada strata keturunan yang diikuti dengan mahar, apakah 88 , atau 77 , atau 66, atau 44 , atau 22, atau 11 . Jika mahar 88 adat memperoleh bagian 8 real, jika mahar 44 adat memperoleh 4 real, jika mahar 22 adat memperoleh 2 real ..."

Dari ayat tersebut bisa diketahui bahwa dalam perkawinan pihak laki-laki harus membayar mahar atau maskawin kepada pihak perempuan, seperti yang diwajibkan oleh ajaran Islam. Besarnya nilai mahar tergantung dari status sosial pihak laki-laki, yang menunjukkan kemampuan untuk membayarnya. Jumlah mahar adalah kelipatan sebelas $(88,77,66,44,22)$, dan adat memperoleh sekitar sepuluh persen dari jumlah mahar tersebut. Nilai mahar dihitung dengan standard mata uang real, yaitu mata uang Arab, yang menunjukkan adanya pengaruh budaya Arab.

\section{Islam Sebagai Identitas Suku Bajo}

Islam telah menjadi bagian penting dalam identitas budaya orang Bajo, yang terbukti dari ayat-ayat dalam naskah Lontarak Assalenna Bajo yang diwarnai oleh nilainilai ajaran Islam sebagai buah pikiran orang Bajo dalam melukiskan kehidupan mereka. Meskipun Islam telah diterima oleh masyarakat Bajo sebagai identitasnya, na- mun penerimaan ajaran Islam tersebut tentu tidak terjadi dengan serta merta. Penerimaan Islam oleh masyarakat Bajo tentu melalui proses negosiasi dan perkembangan terus-menerus, dalam rangka proses pembentukan dan pembangunan identitas mereka. Proses negosiasi ini yang terpenting adalah proses negosiasi antara penerimaan nilainilai Islam dengan kepercayaan tradisional (indigenous belief) mereka sebagai suku laut, dan proses interaksi dengan masyarakat di luar mereka, yaitu dengan orang-orang darat. Oleh karena itu, perlu dilihat konteks sejarah kehidupan orang Bajo, termasuk tentang asal-usulnya, untuk mengetahui proses pembentukan identitasnya.

Dalam beberapa penelitian tentang masyarakat Bajo, didapati bahwa dalam legenda dan cerita rakyat Bajo, orang Bajo mengaku bahwa nenek moyang mereka dahulu berasal dari Johor di Semenanjung Malaya (McAllister, 1996; Hope, 2001; Anwar, 2007; Zacot, 2008; Lapian, 2009). Dalam legenda tersebut dikisahkan bahwa pada zaman dahulu putri raja Malaka hilang dan tenggelam di laut ketika sedang berlayar. Raja Malaka memerintahkan para prajurit untuk mencari putrinya yang hilang itu, dan melarang mereka kembali jika tidak menemukannya. Para prajurit sudah mencari ke berbagai penjuru namun tidak menemukan putri Sang Raja, dan memutuskan tidak kembali ke kerajaan karena takut akan hukuman dari raja. Mereka memilih mengembara di lautan lepas, dan mereka inilah yang menjadi cikal-bakal suku Bajo (Anwar, 2007).

Dugaan yang lebih dekat secara historis adalah ketika Malaka ditaklukkan oleh Portugis pada awal abad ke-16, beberapa prajurit kerajaan Malaka menolak untuk menyerah kepada Portugis dan memilih untuk mengembara di lautan lepas. Inilah asal-usul persebaran orang laut atau orang Bajo ke berbagai wilayah perairan Nusantara dan sekitarnya (Anwar, 2007). Namun demikian, Lapian mempunyai pendapat lain. Menurutnya, penyebaran orang laut atau orang Bajo yang umumnya mengarah ke timur perairan Nusantara bukan karena penak- 
lukan Portugis, namun karena konflik internal kerajaan Malaka sendiri. Para prajurit yang tidak ingin terlibat dan memihak siapa pun dalam konflik politik memilih untuk mengembara di lautan, terutama menuju ke arah timur (Lapian, 2009: 106).

Berdasarkan dugaan bahwa orang Bajo berasal dari Malaka atau Johor di Semenanjung Malaya, maka implikasinya adalah mereka sudah lebih dulu menganut Islam sebelum menjadi suku pengembara laut, mengingat Malaka adalah sebuah kerajaan Islam atau kesultanan. Dengan demikian, mereka membawa serta identitas keislamannya ke mana pun mereka mengembara, hingga akhirnya bermukim di tepi-tepi pantai atau gugusan karang di berbagai wilayah perairan. Namun demikian, salah satu catatan Lapian (2009: 109) menyebutkan bahwa orang-orang laut ini telah menyebar ke arah timur dari Johor ke wilayah kepulauan Sulu, Filipina, sebelum Islam masuk ke wilayah tersebut, sehingga orang-orang laut ini memeluk Islam karena pengaruh dari orangorang Sulu.

Dugaan bahwa nenek moyang orang Bajo berasal dari Semenanjung Malaya dibantah oleh Horst (Hope, 2001), yang menyatakan bahwa orang Bajo mengaku nenek moyangnya berasal dari Johor karena mereka mengalami tekanan dari kesultanan di sekitarnya. Ia memberi contoh seperti orang Bajo di Sulu yang mendapat tekanan dari kesultanan Tausug, sehingga mereka merujukkan nenek moyangnya kepada kesultanan yang lebih tua dan lebih kuat, yaitu kesultanan Johor. Selanjutnya, Horst merujuk kepada penelitian Pallesen (1985) yang menyebutkan bahwa berasal dari rumpun bahasanya, yaitu bahasa proto-Sama, orang-orang Bajo ini berasal dari Filipina. Mereka menyebar ke selatan ke wilayah perairan Sulawesi dari Filipina. Karena dugaan nenek moyang orang Bajo berasal dari Semenanjung Malaya dibantah, maka dugaan bahwa orang-orang Bajo telah memeluk Islam sebelum mereka menjadi pengembara laut juga terbantahkan. Dengan demikian, orang-orang Bajo ini meme- luk Islam karena pengaruh dari kesultanan atau orang-orang darat di sekitarnya.

Di sisi lain, Lapian (2009: 111) juga mengemukakan pendapat yang mendukung, yaitu bahwa orang-orang Bajo di perairan Bone dan Teluk Tomini lebih berorientasi ke kerajaan Bone. Dalam naskah Lontarak Assalenna Bajo sendiri disebutkan bahwa orang-orang Bajo berasal dari daerah Ussu di Luwu, Sulawesi Selatan. Pada suatu ketika, sebuah pohon besar yang disebut Walenreng ditebang sehingga mengakibatkan banjir besar yang membuat para penduduknya mengungsi, termasuk orangorang Bajo yang dipimpin oleh Ipapu hanyut ke laut dan akhirnya terdampar di kerajaan Gowa. Kutipan peristiwa tersebut termuat dalam ayat 8 dan 9 sebagai berikut:

8. “... Ipapu ritubbangngi WalenrengngE nalempe..."

9. "Nasiappimalirenna ri lauu..."

Terjemahannya (Anwar, 2000) sebagai berikut:

8. “...Ipapu menyatakan bahwa pohon Walenreng telah ditebang dan terjadi banjir..."

9. "Banyak yang hanyut ke laut..."

Namun demikian, istilah walenreng sendiri bisa diartikan sebagai runtuhnya sebuah kerajaan, yang dalam proses keruntuhannya itu terjadi pertumpahan darah yang membuat banyak penduduk mengungsi (Anwar, 2006: 1). Karena peristiwa tersebut, orang Bajo mengungsi ke kerajaan Gowa, bahkan salah seorang putri bangsawan Bajo diperistri oleh Raja Gowa. Ketika kerajaan Gowa ditaklukkan oleh kerajaan Bone, orang Bajo memilih untuk tunduk kepada Raja Bone. Oleh Raja Bone, mereka diberi tempat di pesisir timur kerajaan Bone, yang diberi nama BajoE (Anwar, 2006: 2). Kemungkinan orang laut ini disebut orang "Bajo" karena berasal dari nama tempat "BajoE" yang diberikan oleh Raja Bone tersebut.

Apabila ditelusuri lebih jauh, ternyata kisah tentang tumbangnya pohon besar dan terjadinya banjir besar yang menjadi asalusul orang Bajo ini dekat dengan kisah Sawerigading yang berasal dari masyarakat 
Bugis (Hope, 2001). Lebih jauh, kisah tentang asal-usul sebuah suku atau kelompok etnis yang berasal dari sebuah banjir besar juga didapati di beberapa kelompok etnis di Asia Tenggara (Nghiem, 1993). Oleh karena itu, secara tidak langsung, orang-orang Bajo ingin memosisikan identitas diri mereka sejajar dengan orang-orang darat di sekitarnya dengan mengonstruksikan bahwa asal-usul identitas mereka itu satu rumpun dengan orang Bugis (kisah Walenreng dan Sawerigading), orang Melayu (asal-usul dari Semenanjung Malaya), dan orang Islam pada umumnya (sebagai anak-cucu Adam). Itulah mengapa McAllister (1996) mengatakan bahwa sesungguhnya asal-usul orang Bajo ini tetaplah sebagai sebuah spekulasi.

Walaupun orang Bajo mengidentifikasi diri sebagai orang laut, namun kehidupan mereka tidak bisa dipisahkan sama sekali dari daratan. Orang Bajo tetap membutuhkan bahan makanan pokok, seperti beras, sagu, atau umbi-umbian, air tawar, dan kayu bakar, yang hanya bisa diperoleh dari daratan. Sementara itu, orang darat tetap bisa hidup tanpa mengandalkan hasil-hasil laut yang menjadi hasil utama dan mata pencaharian orang Bajo. Dengan keadaan seperti ini, maka posisi tawar orang Bajo menjadi lebih lemah dibandingkan dengan orang darat, karena bagaimana pun juga ketergantungan mereka kepada daratan lebih tinggi dibandingkan orang darat yang tidak terlalu bergantung kepada lautan (Ahimsa-Putra, 2006: 214).

Lemahnya posisi tawar orang Bajo bila dibandingkan dengan orang darat ini antara lain dilukiskan oleh McAllister (1996) bahwa orang-orang Bajo cenderung meminta perlindungan kepada kesultanan di sekitar tempat mereka bermukim dari serangan bajak laut. Dalam naskah Lontarak Assalenna Bajo sendiri disebutkan bahwa orang Bajo harus memberikan kasiwiang atau persembahan kepada Raja Bone sebanyak satu pikul atau satu perahu penuh. Mengenai kasiwiang tersebut disebutkan dalam ayat 349 sebagai berikut:
"Nakkeda Ilolo ri ana-eppona maegaE napada mabberena tassikappala'na, gennei sipikulu napaenre'ni Ilolo ri Bone tanraapii ri Puwanna, makkoniro rimula-appongenna ri kasiwiang sisengngE..."

Terjemahannya (Anwar, 2000) sebagai berikut:

"Berkata Lolo (pemimpin Bajo) kepada anak cucunya yang banyak, maka mereka masingmasing memberi satu kapal, setelah cukup sepikul dibawalah Lolo naik ke Bone di hadapan Baginda (Raja), demikianlah asal-usul persembahannya..."

Dengan lemahnya posisi tawar orang Bajo di hadapan orang darat, maka keadaan tersebut memaksa mereka untuk menerima berbagai pengaruh dari darat. Penyerahan kasiwiang atau persembahan kepada Raja Bone menunjukkan adanya kepatuhan orang Bajo terhadap aturan-aturan yang ditetapkan oleh kerajaan di sekitarnya. Apabila kerajaan di sekitarnya tersebut adalah sebuah kesultanan yang menetapkan nilainilai ajaran Islam dalam aturan-aturannya, maka aturan-aturan itu juga harus dipatuhi oleh orang-orang Bajo. Dari sinilah kemungkinan besar orang-orang Bajo mendapatkan pengaruh ajaran Islam ke dalam kehidupannya.

Sebelum mendapatkan pengaruh ajaran Islam, masyarakat Bajo telah mempunyai keyakinan tradisional mereka sendiri (indigenous belief), yang ajaran-ajarannya tertuang dalam adat, tradisi, dan ritual-ritual tradisional mereka. Bentuk keyakinan tradisional masyarakat Bajo ini antara lain adanya keyakinan spiritual terhadap penguasa laut yang diistilahkan sebagai $M b o$ Ma Dilao. Sebelum pergi melaut, masyarakat Bajo umumnya membaca mantra-mantra tertentu untuk memohon keselamatan dan hasil laut yang banyak kepada Mbo Ma Dilao. Selain itu, masyarakat Bajo juga melakukan ritual dan membaca mantra-mantra untuk memohon kesembuhan kepada $M b o$ Ma Dilao ketika ada anggota masyarakat yang sakit, dan juga untuk memohon perlindungan dan kesejahteraan. 
Setelah mendapatkan pengaruh dari ajaran Islam, masyarakat Bajo kemudian menegosiasikan dan memadukannya dengan keyakinan tradisional mereka, sehingga bentuk-bentuk ritual dan mantra-mantra tersebut menjadi wujud perpaduan antara nilai-nilai ajaran Islam dengan keyakinan tradisional mereka. Oleh karena itulah sebenarnya keberagamaan orang Bajo ini merupakan suatu bentuk sinkretisme antara keyakinan tradisional mereka dengan ajaran-ajaran Islam (Stacey, 2007). Contohnya adalah salah satu bentuk mantra memohon keselamatan yang diucapkan menjelang pergi melaut sebagai berikut (dikutip dari Uniawati, 2006):

\section{Bismillahirrahmanirrahim \\ Opapu oh Mbo Ma Dilao \\ Ombotumbira \\ Daha aku \\ Sasapata madilao \\ (Bismillahirrahmanirrahim \\ Oh Tuhan, Oh Mbo Ma Dilao \\ dan wakilnya \\ jangan saya ditegur \\ dan jangan saya diganggu di laut)}

Sebagaimana tersebut dalam mantra di atas, ucapan "Bismillahirrahmanirrahim" berpadu dengan permohonan kepada $M b o$ Ma Dilao, yang menunjukkan adanya sinkretisme antara keyakinan tradisional masyarakat Bajo dengan ajaran Islam.

Demikianlah, bentuk sinkretisme antara keyakinan tradisional dan ajaran Islam tersebut menunjukkan adanya suatu proses negosiasi serta penerimaan atas ajaran-ajaran Islam dalam konstruksi identitas masyarakat suku Bajo, dalam hubungannya dengan lingkungan hidupnya sebagai orang laut, dan juga dalam hubungannya dengan lingkungan sosialnya, khususnya ketika mereka berhubungan dengan orang-orang darat.

Dari gambaran tersebut, tampak peran Islam sebagai identitas orang Bajo yang strategis dan posisional seperti pendapat Hall (1996). Islam merupakan salah satu strategi orang Bajo dalam mempertahankan hidupnya, yaitu dengan mengadopsi nilai-nilai
Islam yang berasal dari darat ketika mereka harus berhubungan dengan orang darat. Secara posisional, orang Bajo tampil memosisikan diri sebagai orang Islam ketika berhubungan dengan orang darat, sehingga mereka lebih mudah diterima. Di sinilah tampak jelas bahwa konstruksi identitas masyarakat Bajo juga ditentukan oleh lingkungan sosialnya, seperti pendapat Sen (2006) serta Berger dan Luckmann (1966), yaitu ditentukan oleh hubungan mereka dengan orang darat. Identitas keislaman orang Bajo juga selalu mengalami proses negosiasi (Hall, 1996) atau dialektika (Berger dan Luckmann, 1966), yaitu ke dalam berdialektika dengan keyakinan tradisional masyarakat Bajo, dan ke luar berdialektika dalam hubungan dengan orang-orang darat.

Dalam kerangka teori Hans Mol (1986), Islam merupakan bentuk sakralisasi identitas masyarakat Bajo, yang menjamin ikatan sosial di dalam masyarakat Bajo maupun hubungannya dengan orang-orang darat. Bentuk sakralisasi identitas tersebut antara lain: (1) Islam menyediakan nilai-nilai yang bisa menjadi petunjuk hidup bagi masyarakat Bajo; (2) Islam menjadi dasar bagi aturan-aturan yang berlaku di dalam masyarakat Bajo, di antaranya adalah aturan tentang perkawinan; ketiga, Islam mampu mengembangkan keterikatan emosional, komitmen, dan kebersamaan di dalam masyarakat Bajo maupun dalam hubungannya dengan orang darat sebagai sesama Muslim; (3) bentuk sakralisasi identitas tersebut telah tertuang dalam naskah Lontarak Assalenna Bajo sebagai catatan dan ungkapan masyarakat Bajo tentang kehidupan mereka sendiri.

\section{SIMPULAN}

Islam telah menjadi bagian penting dalam identitas budaya suku Bajo, baik tercermin dalam kehidupan mereka sehari-hari maupun yang tercantum dalam naskah Lontarak Assalenna Bajo sebagai bentuk kearifan budaya Bajo yang berisi catatan tentang kehidupan masyarakat Bajo yang ditulis oleh mereka sendiri. Ikrar keyakinan pada Tuhan 
Allah dan Nabi Muhammad serta pengakuan Adam dan Hawa sebagai nenek moyang mereka dalam naskah tersebut menunjukkan keimanan orang Bajo terhadap ajaran Islam. Lebih jauh, nilai-nilai ajaran Islam juga telah menjadi dasar bagi aturan-aturan yang berlaku dalam masyarakat Bajo, salah satunya adalah mengenai aturan tentang perkawinan.

Walaupun Islam telah diterima oleh masyarakat Bajo, proses penerimaan tersebut tidak terjadi begitu saja, namun melalui proses negosiasi dan perkembangan terusmenerus. Orang Bajo memang bukan orang Islam dari awal sebelum mereka menjadi pengembara laut, namun mereka menerima pengaruh Islam dari orang-orang darat di sekitarnya, sebagai akibat hubungan antara orang Bajo dengan orang darat. Dalam konteks naskah Lontarak Assalenna Bajo, yang ditulis oleh orang Bajo di BajoE di perairan teluk Bone, masyarakat Bajo menerima pengaruh Islam dari hubungannya dengan orang-orang dari kerajaan Bone.

\section{DAFTAR PUSTAKA}

Ahimsa-Putra, H.S., 2006, Strukturalisme Levi-Strauss, Yogyakarta: Kepel Press.

Anonim, Lontarak Assalena Bajo, terjemahan Anwar, 2000, Jakarta: Program Penggalakan Kajian Sumber-sumber Tertulis Nusantara, Ditjen Dikti Depdiknas.

Anwar, 2007, Etnik Bajo: Bermula dari Prajurit Kerajaan, Melayu Online: www. melayuonline.com

Anwar, 2006, Kajian Pendidikan dan Kebudayaan Bajo, Tinjauan Historis dan Kontemporer, makalah Seminar Perumusan Naskah Sejarah (tidak terbit), Kendari: Universitas Haluoleo.

Berger, P. dan Luckmann, T., 1966, The Social Construction of Reality, New York: Anchor Book.

Chou, C., 2003, Indonesian Sea Nomads, London: IIAS-RoutledgeCurzon.
Hall, S., 1996, "Who Needs Identity?", dalam Hall, S. dan du Gay, P. (eds), Questions of Cultural Identity, London: Sage Publications.

Hope, S., 2001, Outcasts of the Islands, London: HarperCollins Publishers.

Lapian, A.B., 2009, Orang Laut, Bajak Laut, Raja Laut: Sejarah Kawasan Laut Sulawesi Abad XX, Jakarta: Komunitas Bambu.

Liliweri, A., 2002, Makna Budaya dalam Komunikasi Antarbudaya, Yogyakarta:

LKIS.

Marihi, L., 2007, Kepemimpinan Kepala Madrasah Tsanawiyah Mantigola dalam Membina Hubungan Sekolah Dengan Masyarakat Bajo, M.A. Tesis (tidak terbit), Kendari: Universitas Haluoleo.

McAllister, K.E., 1996, Ethnic Identity and Changing Relations of Dependency Among the Bajo Fishers of Central Sulawesi, Disertasi (tidak terbit), Halifax, Nova Scotia: Dalhousie University.

Mol, H., 1986, "Religion and Identity: A Dialectic Interpretation of Religious Phenomena", dalam Hayes, V.C. (ed.), Identity Issues and World Religions, Bedford Park, Australia: Australian Association for the Study of Religion.

Nghiem, D.V., 1993. "The Flood Myth and the Origin of Ethnic Groups in Southeast Asia", Journal of American Folklore, Vol. 106, No. 421: 304-337.

Nimmo, H.A., 1972, The Sea People of Sulu: a Study of Social Change in the Philippines, San Fransisco, USA: Chandler Publishing Company.

Nimmo, H.A., 2001, Magosaha: an Ethnology of the Tawi-tawi Sama Dilaut, Manila, the Philippines: Atteneo de Manila University Press.

Pallesen, A.K., 1985, Culture Contact and Language Convergence, Manila, the Philippines: Linguistic Society of the Philippines. 
Sather, C., 1997, The Bajau Laut: Adaptation, History, and Fate in a Maritime Fishing Society of South-Eastern Sabah, Kuala Lumpur, Malaysia: Oxford University Press,

Sen, A., 2006, Identity and Violence, London: Penguin Books.

Sopher, D.E., 1965, The Sea Nomads: a Study Based on the Literature of the Maritime Boat People of South East Asia, Si- ngapore: National Museum of Singapore.

Uniawati, 2006, Fungsi Mantra Melaut pada Masyarakat Suku Bajo di Sulawesi Tenggara, Kendari: Kantor Bahasa Provinsi Sulawesi Tenggara,

Zacot, F.R., 2008, Orang Bajo, Suku Pengembara Laut, terj. Fida Muljono dan Ida Budi Pranoto, Jakarta: GramediaEFEO-FJP. 